\title{
The Existence of Local Wisdom Values of South Sumatra Community in Strengthening National Integration
}

\author{
Umi Chotimah, Alfiandra, Emil El Faisal, Sulkipani, Camellia \\ FKIP \\ Universitas Sriwijaya \\ Palembang, Indonesia \\ sulkipani@fkip.unsri.ac.id
}

\begin{abstract}
The aims of this study is identifying the local wisdom values of the people of South Sumatra in strengthening national integration. The background of this research is a variety of social events are nuanced intolerant, so potential cause disintegration. That Indonesia has values that characterize unity in diversity that becomes capital to realize national integration the approach used in this research is qualitative approach with case study method. The social situation in this research is community in South Sumatera covering community's tribe of Komering, Ogan, Pasemah, and Palembang which consists of bridal couple, bridal parent, adat chairman, and government element. Data collection techniques used are the techniques of observation, interviews, and documentation, while data analysis methods using qualitative methods consisting of data reduction, data presentation, and data verification/ withdrawal of conclusions. The findings of the field show that in general the values of local wisdom of the people in the fifth marriage's custom include divine values, such as praying in every process performed, then the value of unity, which can be seen from the cooperation in the process of preparation and marriage implementation. And the value of democracy, which can be seen from the deliberation or mutual help that is internalized in the process. Thus, the values of local community wisdom are basically values that are generally available in every region that can strengthen national integration. Based on these findings, it is expected that the community will always internalize the values of local wisdom in the life of society, nation, state to realize national integration.
\end{abstract}

Keywords-integration; local wisdom; national; values

\section{INTRODUCTION}

Indonesia is a country that is cultured. Cultural wealth owned by Indonesia as a nation making the nation the sake noble values in the governance of life of society, nation, and State. Philosophically, the sublime value of nation's culture to be one of the basic sources of the country's Pancasila Indonesia. This indicates that public life is inseparable from the culture of the nation of Indonesia itself as the identity and personality of the nation. As a nation that is rich in culture, national culture consisting of regional culture spread throughout the archipelago with all its philosophical meaning, uniqueness, as well as the value of benefits that are called with the values of local wisdom. Local wisdom is essentially a sublime cultural values of the area that is believed to be the truth and its usefulness in supporting community living activities. Local wisdom covers all forms of knowledge, beliefs, understandings, insights, as well as custom or ethics that guide human behaviour in life in ecological communities [1]. Local wisdom values in each region has its own distinctiveness in accordance with characteristics belonging to the community of his followers.

South Sumatra on society for example, which consists of a few scattered tribes in each city. South Sumatra has four major tribes namely Komering, Ogan, Pasemah, and Palembang, and several other tribes. Local wisdom society South Sumatra is reflected in the activity of public life according each tribe as in customary marriages.

Custom wedding society South Sumatra done according to custom is believed to be by each community. Although globalization has brought an impact on the course of the wedding customs of the land process, but will not reduce the meaning of the value contained in each of the stages. Each stage in the custom of the marriage illustrates the values of local wisdom concerned community, both on the process before, during, and after the wedding day.

Basically, local wisdom values each region has the same base that is the country's basic values of Pancasila. So although each area has a different but local wisdom values that in it remains of Pancasila. Thus, the existence of local wisdom values it is important to be very guarded in the effort of realizing national integration.

\section{THEORETICAL}

Local wisdom community is a living tradition in the community and is believed to be the truth because it has a philosophical values, so that it becomes the Community guidelines in carrying out the activity of his life. Local wisdom sublime cultural values of society to set the order of people's lives [2]. However, the process of interaction and socialization of society in the era of globalization provides a great influence for the possibility the values of local wisdom. The existence of the very values determined from the pattern of her attention 
and appreciation society. Philosophically, the cultural values of the community holding the strategic function in the process of a nation and a country Indonesia.

That nation's culture is one of the basic sources from country Indonesia, Pancasila. In other words, that nation's culture on Pancasila Indonesia itself (causa material). Local wisdom values of society in Indonesia in principle reflect basic values of Pancasila which is a philosophical foundation and unite the nation. This means that if the local wisdom values in public life will provide a positive influence for society against pancasila. Thus, the values of local wisdom can strengthen national integration.

\section{METHOD}

This research was conducted in four tribes in the area of South Sumatra comprised of Tribal Histories, Pasemah, Ogan, and Palembang in Ogan Komering Ulu Timur, Lahat, Ogan Ilir, and Palembang. The tribe's fourth assignment with the consideration that the tribes are the tribes of the great representative and with the community of South Sumatra Province in General. The respondents in this study is the fourth indigenous peoples from the tribe as well as other parties that have the competence against cultural customs of marriage from each tribe (purposive sampling). This study used a qualitative research approach, on the situation it is natural (natural setting) which requires that the occurrence of direct interaction between researchers with the respondent.

As for the method used is descriptive research method. Descriptive research with consideration being able to describe a phenomenon with scientific procedures to respond to problems in actual [3]. The specified data collection techniques are techniques of observation, interviews, and documentation. The next data processed using qualitative analysis technique which contains three stages, namely: data reduction (selection and simplification of raw data), the presentation of data, and verification of data or conclusions [4]. The third stage is a unified whole in the process of collection and analysis of data because the collection and analysis of data take place continuously.

\section{RESULT AND DISCUSSION}

Focus on research is local wisdom values community on the wedding ceremony of tribal community Histories, Komering, Ogan, Pasemah, and Palembang. The ceremony includes the stages before the wedding, at the time of the marriage, and after the wedding reception. Based on the data that has been collected it is known that local wisdom values community breakfast buffet in every custom wedding procession. For more details can be seen in the following table.
TABLE I. LOCAL Wisdom VALUES COMMUNITY IN PROCESSION BEFORE THE WEDDING DAY

\begin{tabular}{|c|c|c|c|}
\hline Komering & Ogan & Pasemah & Palembang \\
\hline $\begin{array}{l}\text { The } \\
\text { application } \\
\text { process is } \\
\text { called } \\
\text { Pengatu, } \\
\text { which } \\
\text { describes } \\
\text { the values } \\
\text { of the } \\
\text { divinity, } \\
\text { humanity, } \\
\text { and } \\
\text { consultativ } \\
\text { e. The } \\
\text { values } \\
\text { visible in } \\
\text { the } \\
\text { application } \\
\text { process that } \\
\text { involves } \\
\text { not only the } \\
\text { bride but } \\
\text { also the } \\
\text { Governmen } \\
\text { t as village } \\
\text { chief, and } \\
\text { custom } \\
\text { elements by } \\
\text { the } \\
\text { Chairman } \\
\text { of the local } \\
\text { customs. } \\
\text { The } \\
\text { purpose of } \\
\text { this process } \\
\text { is held to } \\
\text { apply for } \\
\text { and talk } \\
\text { about } \\
\text { things that } \\
\text { are needed } \\
\text { for a } \\
\text { wedding }\end{array}$ & $\begin{array}{l}\text { The } \\
\text { application } \\
\text { process is } \\
\text { called } \\
\text { Berasan, } \\
\text { which } \\
\text { describes } \\
\text { the value } \\
\text { ketuhahana } \\
\text { n, } \\
\text { humanity, } \\
\text { and } \\
\text { populist. At } \\
\text { this stage } \\
\text { Like other } \\
\text { indigenous } \\
\text { tribal } \\
\text { histories, } \\
\text { the } \\
\text { prospective } \\
\text { bridegroom, } \\
\text { family, } \\
\text { community, } \\
\text { the village } \\
\text { chief, and } \\
\text { the head of } \\
\text { the custom } \\
\text { comes to the } \\
\text { home of } \\
\text { prospective } \\
\text { bride with } \\
\text { the aim to } \\
\text { discuss the } \\
\text { agenda of } \\
\text { the next } \\
\text { wedding }\end{array}$ & $\begin{array}{l}\text { The } \\
\text { application } \\
\text { process is } \\
\text { called } \\
\text { ngantat } \\
\text { palayan. } \\
\text { At this } \\
\text { stage the } \\
\text { prospectiv } \\
\text { e } \\
\text { bridegroo } \\
\text { m comes } \\
\text { to the } \\
\text { home of } \\
\text { the } \\
\text { prospectiv } \\
\text { e bride and } \\
\text { their } \\
\text { families, } \\
\text { the } \\
\text { communit } \\
\text { y, the } \\
\text { village } \\
\text { chief and } \\
\text { the head of } \\
\text { customs to } \\
\text { apply for } \\
\text { and } \\
\text { discussing } \\
\text { the process } \\
\text { of } \\
\text { marriage. } \\
\text { The value } \\
\text { of people's } \\
\text { very } \\
\text { creamy } \\
\text { feel in this } \\
\text { process }\end{array}$ & $\begin{array}{l}\text { The } \\
\text { application } \\
\text { process is } \\
\text { called mutus } \\
\text { kato. With } \\
\text { the purpose } \\
\text { of } \\
\text { application } \\
\text { in General, } \\
\text { involves not } \\
\text { only the } \\
\text { prospective } \\
\text { bridegroom } \\
\text { and bride's } \\
\text { family but } \\
\text { also the } \\
\text { surrounding } \\
\text { communitie } \\
\text { s, the } \\
\text { elements of } \\
\text { governance } \\
\text { such as the } \\
\text { RT and RW, } \\
\text { as well as } \\
\text { the } \\
\text { Chairman of } \\
\text { the customs. } \\
\text { The value of } \\
\text { this process } \\
\text { is reflected } \\
\text { in the value } \\
\text { of the } \\
\text { Godhead, } \\
\text { unity, and } \\
\text { consultative }\end{array}$ \\
\hline
\end{tabular}

TABLE II. LOCAL WISDOM VALUES OF SOCIETY IN THE PROCESSION WHEN THE WEDDING DAY

\section{\begin{tabular}{l|l|l|l} 
Komering & Ogan & Pasemah & Palembang
\end{tabular}}

The process of Covenant of marriage on four tribes in principle have in common. The show began with the reading of the Holy Quran verses, words of welcome, prayer, and continued with the show that is the reading of the consent by the prospective bridegroom, the reading of the taklik marriages, and dilanjtkan the ritual by the bride to both parents and invited guests. The value of the breakfast buffet on the process of this divinity, humanity, and unity 
TABLE III. LOCAL WISDOM VALUES OF SOCIETY IN A PROCESSION AFTER THE WEDDING DAY

\begin{tabular}{|c|c|c|c|}
\hline Komering & Ogan & Pasemah & Palembang \\
\hline $\begin{array}{l}\text { There is a } \\
\text { procession } \\
\text { to Sadai } \\
\text { called } \\
\text { Sabai, that } \\
\text { is gathering } \\
\text { the family } \\
\text { of the } \\
\text { bridegroom } \\
\text { and women } \\
\text { gathered at } \\
\text { the family's } \\
\text { home to } \\
\text { discuss the } \\
\text { term bride } \\
\text { or the } \\
\text { bride's } \\
\text { family } \\
\text { between } \\
\text { calls. In this } \\
\text { process the } \\
\text { value } \\
\text { breakfast } \\
\text { buffet is the } \\
\text { value of the } \\
\text { consultativ } \\
\text { e }\end{array}$ & $\begin{array}{l}\text { At this } \\
\text { stage the } \\
\text { value that } \\
\text { is } \\
\text { represented } \\
\text { is the value } \\
\text { of the } \\
\text { Godhead, } \\
\text { from } \\
\text { whom the } \\
\text { bridegroo } \\
\text { m will take } \\
\text { four of } \\
\text { tailors who } \\
\text { would } \\
\text { rapid } \\
\text { thrusting } \\
\text { into the } \\
\text { mattress } \\
\text { the bride as } \\
\text { a symbol } \\
\text { of } \\
\text { salvation. }\end{array}$ & $\begin{array}{l}\text { At this } \\
\text { stage there } \\
\text { is a } \\
\text { process of } \\
\text { Lingkok'a } \\
n \text { or youth } \\
\text { events, as } \\
\text { a sign of } \\
\text { joy have } \\
\text { been } \\
\text { invited, } \\
\text { weddings. } \\
\text { The value } \\
\text { is the value } \\
\text { of a Union } \\
\text { breakfast } \\
\text { buffet }\end{array}$ & $\begin{array}{l}\text { There is an } \\
\text { event called } \\
\text { Munggah or } \\
\text { wedding } \\
\text { receptions } \\
\text { with the aim } \\
\text { to give } \\
\text { thanks and } \\
\text { share } \\
\text { happiness/jo } \\
\text { y with the } \\
\text { relatives of } \\
\text { relatives and } \\
\text { the local } \\
\text { community. } \\
\text { The value of } \\
\text { tergamar is } \\
\text { the value of } \\
\text { the divinity, } \\
\text { humanity, } \\
\text { and unity }\end{array}$ \\
\hline
\end{tabular}

The table shows that Indigenous Tribal wedding procession in the Histories, Pasemah, Ogan, Palembang and contains local wisdom values that reflect the notability of the nation as a result of the high value of cultural civilization. Such values surely stems from the nation's ideology Pancasila which is able to strengthen the unity of the nation through governance each stage of the procession before the wedding day, the day of the wedding, and after the wedding day takes place.

Before the wedding day starts from the moment of application, at the time of marriage is the Covenant of marriage, and events during the wedding as an event after the wedding day. In process before the wedding day, that cover events there is local wisdom values on a society that values of Pancasila namely human values, unity, and consultative. The value of humanity looks upon arrival the prospective bridegroom with a parent or who represent the home of prospective bride as a form of homage to the male party to the women. Next is the value of a Union which can be observed from the process of intermingling between the two families of prospective brides with local communities regardless of social background.

As for the highly consultative value clearly visible at the time arranged to determine the day of the wedding and things associated with the procession. After the application process, the next is the process at the time of the wedding day (marriage contract). Local wisdom values which appear in this procession is the value of the Godhead, human values, and the value of unity. At the time of starting the Covenant of marriage held a reading of the Quran, the Font, and the sermon of marriage, as well as the praises to God Almighty. That illustrates that the value of the Godhead coloring procession to Covenant of marriage.
Next is a human values can be seen at a time when the bride and groom bow to his parents to invoke prayers of blessing and apologies as a sign of filial piety to parents, as well as greet the invited guests were present as a form of Thank you for your presence as well as appealing for prayers for blessing. Then the value of unity breakfast buffet when both couple mingling in one united interaction with the whole family and guests in attendance. The next process is the Thanksgiving marriage, describing the existence value of the divinity, humanity, and justice.

The value of the Godhead can be seen when the bride and groom as well as all guests were present to say a prayer as a form of gratitude upon this Covenant of marriage. After that, all guests who attend enjoy a meal prepared by the family, at the moment the humanitarian values of the breakfast buffet. Based on the description it is understood that local wisdom values on society' tribes of Ogan, Komering, Pasemah, and Palembang and still stayed up until now, there are changes in certain stages, but it does not reduce the meaning of the existing values. That is because the local wisdom as wisdom is sourced on the values that are considered good and right and persist for a long time [5]. In the context of the marriage customs of the values that the values are internalized divinity, humanity, unity, which is a consultative value contained in the Pancasila.

Thus, the values of the local community can become an instrument of strengthening national integration. It is inseparable from the nature of local wisdom as knowledge itself intergenerational useful to the community as it relates to family, neighbors, community, and the environment [6]. Local wisdom community as the nation's ethnic identity and Indonesia is the dynamic conditions that should be understood by every element of society. This means that changing times will bring the influence for the local wisdom values of society. Therefore, in order for the identity and the identity of the nation maintained absolute seriousness required from all parties to keep the values of existing local wisdom. The existence of local wisdom values give meaning to the existence of a State, because according to Toyenbee so that the nation and the State of Indonesia still exist in the middle of torrential currents of globalization then Indonesia society should keep putting ethnic and national identity as a basis to act in the modern era [7].

\section{CONCLUSION}

Based on the results and the discussion of it can be concluded that the values of local wisdom society South Sumatra still exist until nowadays, it can be seen among them on the procession of the custom wedding that internalize values local wisdom in the process before the wedding day, the day of the wedding, and after the wedding day. The values in the value of the values of Pancasila State basic divinity, humanity, unity, populist, and justice. Thus, the values of local wisdom can strengthen national integration. Based on these conclusions, expected to all elements of society in order to always keep the local wisdom of society, and actualization in the life of society 


\section{ACKNOWLEDGMENT}

On this occasion, the authors present thanks to the Chairman and the LPPM Sriwijaya University, Dean FKIP Sriwijaya University who have facilitated this research, as well as the respondents who gave the best response in the completion this research.

\section{REFERENCES}

[1] A.S. Keraf, Etika Lingkungan. Kompas. Jakarta, 2002.
[2] R. Sibarani, KEARIFAN LOKAL: Hakikat, Peran, dan Metode Tradisi Lisan. Jakarta: Asosiasi Tradisi Lisan (ATL), 2012.

[3] Sugiyono, Metode Penelitian Kuantitatif, Kualitatif dan R\&D. Bandung; CV. Alfabeta, 2011.

[4] Milles and Huberman, Analisis Data Kualitatif. Jakarta: Universitas Indonesia Press, 1992

[5] I. Mariane, Kearifan Lokal Masyarakat Hutan Adat. Rajawali Pres. Jakarta, 2014.

[6] K. Kongprasertamorn, "Local Wisdom, Environmental Protction and Community Development: The Clam Farmers in Tambon Bangkhunsai, Phetchaburi Provinc," Thailand. Manusya : Jorunal of Humanities, vol. 10, no. 1, 2007.

[7] Kaelan and A. Zubaedi, Pendidikan Kewarganegaraan Untuk Perguruan Tinggi. Yogyakarta: Paradigma, 2007. 